УДК 621.891.

DOI: $10.18372 / 0370-2197.3(88) .14928$

О. В. МЕЛЬНИК ${ }^{1}$, І. В. СМІРНОВ ${ }^{2}$, В. Ф. ЛАБУНЕЦЬ ${ }^{1}$, А. В. ЧОРНИЙ ${ }^{2}$.

${ }^{1}$ Національний авіаційний університет, Київ

${ }^{2}$ Національний технічний університет Украйни «КПІ ім. І. Сікорського», Украйна

\title{
ДОСЛІДЖЕННЯ ЗНОСОСТІЙКОСТІ ПЛАЗМОВИХ ПОКРИТТІВ В УМОВАХ АБРАЗИВНОГО ЗНОШУВАННЯ
}

Наведено результати експериментальних досліджень технології нанесення композиційних плазмових покриттів на основі нікелю $i$ заліза та їх зносостійкість в умовах нежорсткозакріпленого абразиву $\mathrm{SiO}_{2}$. Встановлено механізм зношування покриттів, які наносились на леговану сталь ЗОХГСА для даних умов тертя. Обтрунтовано перспективність і доцільність застосування композичійних плазмових покриттів для деталі вузлів тертя авіаційної техніки, які працюють в умовах абразиву.

Ключові слова: композиційні плазмові покриття, абразив, структура, зносостійкість.

Вступ. Надійність і довговічність сучасної техніки безпосередньо пов'язана 3 працездатністю вузлів тертя. Характер та інтенсивність зношування визначається умовами механічного навантаження , наявністю і складом середовища, його хімічної активності, властивостей контактуючих матеріалів. Все це визначає одну із основних характеристик пари тертя зносостійкість.

На сьогодні основним шляхом підвищення зносостійкості робочих поверхонь деталей машин, інструментів та технологічного обладнання $\epsilon$ наступне: 1) зміна хімічного складу поверхневих шарів їх легуванням для створення структур, які будуть чинити опір процесам зношування, а в особливості таким катастрофічним як схоплення, фретинг-корозія, абразивне зношування; 2) механічний і (або) тепловий вплив на поверхневі шари металу, який обумовлює структурні перетворення, що сприяє забезпеченню працездатності пар тертя; 3) нанесення на поверхню тертя зносостійких покриттів [1].

Пріоритетним направленням у технологічних процесах поверхневого зміцнення деталей вузлів тертя авіаційної техніки (АТ) являються методи газотермічного напилення, а саме плазмового.

Огляд публікацій та аналіз невирішених проблем. Аналіз статистичних даних дефектації деталей АТ при виконанні капітального ремонту дозволяє стверджувати, що найбільша кількість їх бракується з причин суттєвого зносу, втомного руйнування та корозії. Особливо це стосується деталей вузлів тертя, які працюють в умовах абразивного, ерозійного, газо- і гідроабразивного зношування та ін.

Зауважимо, що питанням абразивного зношування матеріалів присвячено велика кількість досліджень [2-9 та ін.], які показали складність цього механізму зношування. Аналіз літературних джерел свідчить про те, що на інтенсивність абразивного зношування великий вплив здійснюють форма, твердість і геометричні розміри абразивних частинок, навантаження, швидкість переміщення абразиву, фізико- механічні властивості поверхні деталі яка зношується. Різновиди цих чинників, а також їх неоднозначний вплив на процеси абразивного зношування ускладнюють розроблення методів захисту від зносу деталей трибовузлів. 
Визначенню основних видів зношування і діагностики деталей АТ, механізму та кінетики їх розвитку присвячені роботи О.Ф. Аксьонова, В.А.Богуслаєва, Д.М. Гаркунова, М.Л. Голего, М.В. Кіндрачука, К.О. Крилова, Б.І. Костецького В.М. .Лозовського та ін [10]. Що стосується абразивного зношування, то цей процес $є$ основним для деталей шасі літаків типу Ан, так як вони часто експлуатуються на грунтових аеродромах. У зв'язку з цим розроблення заходів 3 підвищення працездатності деталей вузлів тертя АТ є однією з першочергових задач.

Враховуючи інтенсивність старіння авіаційного парку, питання відновлення зношених деталей за допомогою сучасних технологічних методів $є$ актуальним.

Мета роботи. Дослідження впливу і складу структури плазмових покриттів на зносостійкість конструкційної сталі 30ХГСА в умовах абразивного зношування.

Методи дослідження. Методична частина роботи складається із трьох єтапів: 1) методики нанесення плазмових покриттів; 2)методики визначення зносостійкості на машині тертя; 3)методів визначення фізико-механічних властивостей мікроструктури і фазового складу покриттів.

Плазмове напилення композиційних порошків на основі нікелю і заліза здійснювали на промисловій установці УПНС-304 модернізованим плазмотроном з частково винесеною дугою і додатковим обдуванням плазмового струменя концентричним потоком захисного газу [11]. Струм дуги встановлювався в межах 80-90 А, при напрузі 35-50 В, продуктивністю до 4 кг/год із загальною витратою плазмо утворюючого газу, транспортуючого і захисного газу (аргону) 5л/хв. Завдяки таким конструктивним особливостям і технологічним режимам, характер течії плазмового струменя був близький до ламінарного, що забезпечувало сприятливі умови для збереження та перенесення у покриття порошкових матеріалів.

Трибологічні дослідження проводили в умовах вільно не жорстко- закріпленого абразиву на стандартній установці [12]. В якості абразиву використовували кварцевий пісок ( $\mathrm{SiO})$ трьох фракцій. Знос визначали на електронних вагах 3 точністю до 0,0001г.

Фізико-механічні властивості, як самого покриття, так і системи «основапокриття» визначали за результатами механічних випробувань на згин на установці моделі KOGEL (Німетчина). Випробування проводили на зразках $з$ плазмовими покриттями товщиною 50-100 мкм, які були нанесені на один бік зразка. Мікроструктура і хімічний склад покриттів визначали за допомогою скнуючого електронного мікроскопу з енергодисперсним мікроаналізатором РЕМ-106. Дифрактометричний аналіз проводили на рентгенівському дифрактометрі Rigaku Ultima IV. Мікротвердість отриманих покриттів визначали на мікротвердомірі ПМТ-3. Міцність зчеплення покриття з основою визначали у відповідності стандарту ASTM C633.

Результати дослідження та їх обговорення. Зовнішній вигляд порошкового матеріалу на основі нікелю подано на рис. 1.

Вихідна геометрична форма частинок даного порошку різнобічна, що ускладнює технологічний процес нанесення покриття.

Частинки порошкового матеріалу на основі заліза мали кулькову форму, що забезпечувало технологічність процесу плазмового напилення рис. 2.

Зносостійкість сталі 30ХГСА до напилення і 3 покриттям на рис. 3. Як видно iз рис. 3, зносостійкість композиційних плазмових покриттів 3 наповнюючими інтерметалідами вище у порівнянні зі зносостійкістю легованої сталі 30ХГСА. 


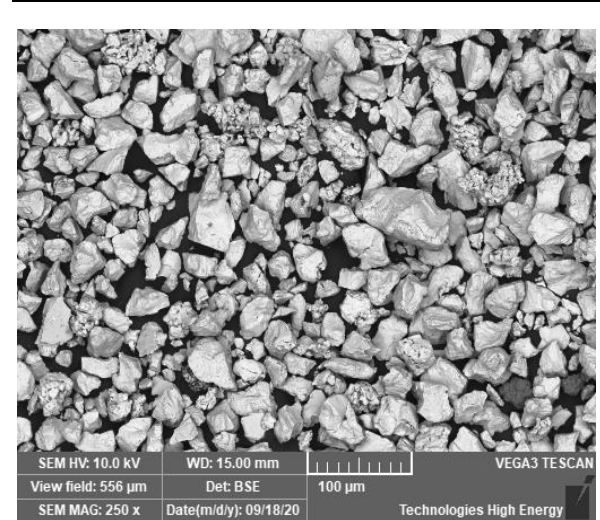

Рис. 1. Зовнішній вигляд порошкового матеріалу на основі нікелю

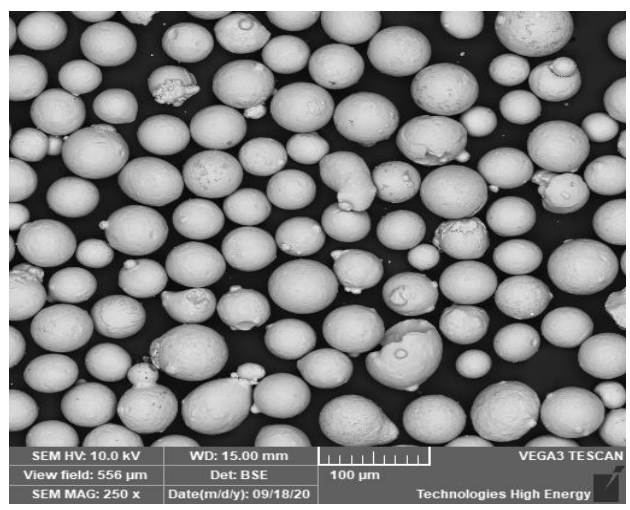

Рис. 2. Зовнішній вигляд порошкового матеріалу на основі заліза

Зносостійкість сталі 30ХГСА до напилення і з покриттям на рис. 3.

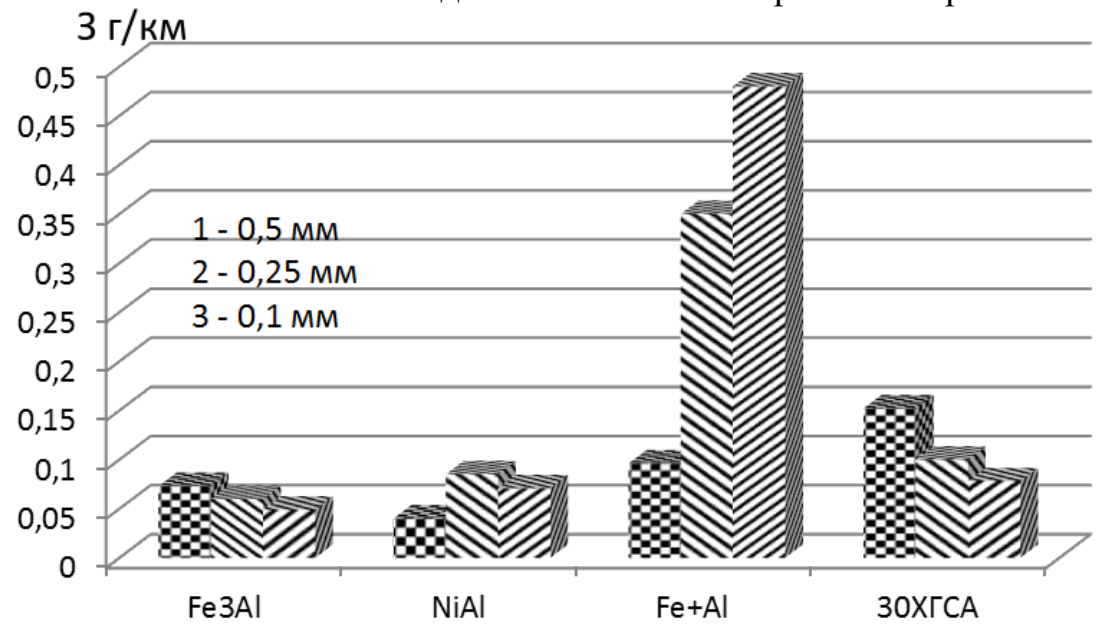

Рис. 3. Знос сталі 30ХГСА з плазмовими покриттями у залежності від фракції абразивних зерен $\mathrm{SiO} 2$ (1-50мкм, 2-25 мкм, 3-10 мкм, справа - на ліво)

А покриття структурного складу «механічна суміш» залізо-алюміній володіють низькими триботехнічними характеристиками.

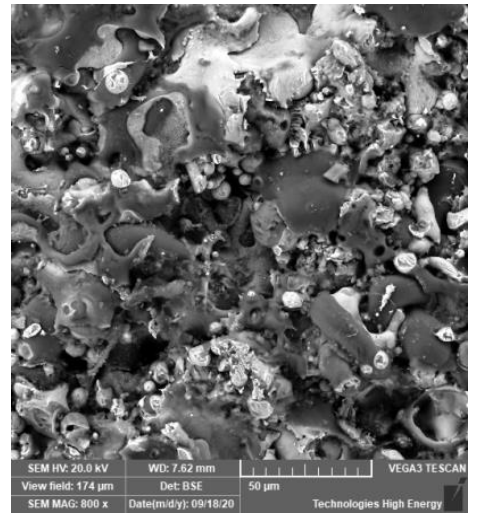

$a$

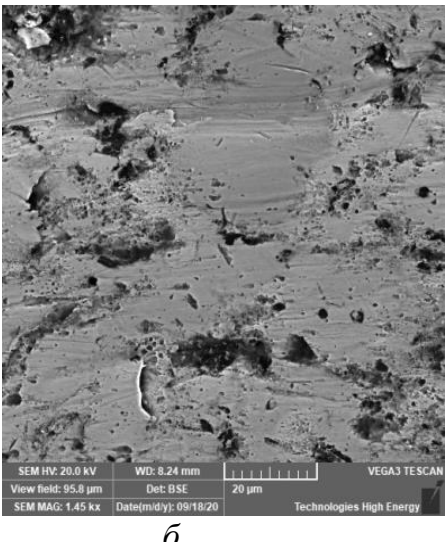

6

Рис. 4. Мікрофотографії композиційного плазмового покриття NiAl: $a$ - вихідна поверхня; $\sigma$ - поверхня після тертя 
Механізм абразивного зношування плазмових покриттів на основі нікелю (рис. $4, a$ ) визначається не тільки їх міцністю, а і ступенем пружного деформування, при зануренні твердих абразивних частинок (зерен), які у процесі тертя у більшості випадків залишаються цілими. Металографічні дослідження поверхонь тертя покриттів свідчать про шаржування твердих частинок, що обумовлено їх більш високою твердістю у порівнянні з матричним матеріалом, завдяки високої пластичності якого процеси мікрорізання відсутні (рис. 4, б). Аналіз робочих поверхонь покриття на основі заліза (рис. 5, a) і після тертя (рис. 5, б) дають можливість стверджувати, що у даних умовах тертя відбувається пластичне деформування залізної основи покриття без глибоких виривів та вузлів схоплення. При цьому шорсткість робочих поверхонь покриття зменшується.

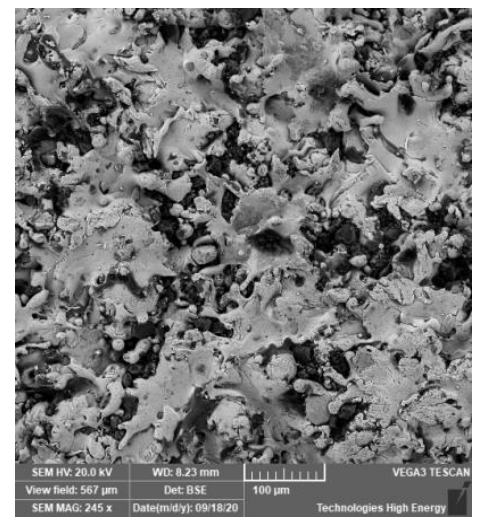

$a$

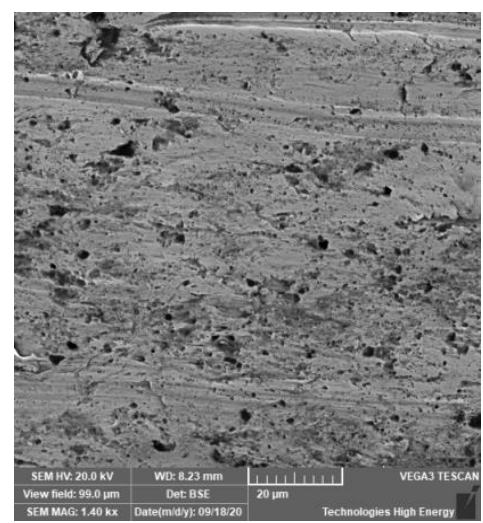

$\sigma$

Рис. 5. Мікрофотографії композиційного плазмового покриття $\mathrm{Fe}_{3} \mathrm{Al}$ : $a$ - вихідна поверхня; $\sigma$ - поверхня після тертя

Для плазмового покриття величина абразивних часток незначною мірою впливає на знос, а знос сталі 30ХГСА зі збільшенням фракції абразиву зростає.

Таким чином результати проведених досліджень $є$ основою для заключення наступних висновків: 1)установлено механізм абразивного зношування плазмових покриттів для даних умов випробувань; 2) обгрунтовано перспективність і доцільність застосування плазмового напилення для нанесення покриттів на деталі вузлів тертя авіаційної техніки які працюють в умовах абразиву

\section{Список літератури}

1. Трибологія: підруч./ М.В. Кіндрачук, В.Ф. Лабунець, М.І. Пашечко, Є.В.Корбут.-К.: Вид-во Нац.авіац.ун-ту»НАУ-друк». -2009.-392с.

2. Виноградов В.Н. Изнашивание при ударе //В.Н. Виноградов, Г.М.Сорокин, А.Ю. Албагачев. - М.: Машиностроение, 1982.-311с.

3. Гаркунов Д.Н. Повишение износостойкости деталей конструкций самолётов / Д.Н Гаркунов, А.А.Поляков. - М.: Машиностроение, 1973.-200 с.

4. Дворук В.И. Научные основы повышения абразивной износостойкости деталей машин / В.И. Дворук К.: КМУГА, 1987.- 101с.

5. Кащеев В.Н. Абразивное разрушение твёрдых тел / В.Н. Кащеев. - М.: Наука, 1970. $-248 \mathrm{c}$.

6. Надёжность и долговечность машин/ Б.И. Костецкий, И.Г.Носовский, Л.И. Бершацкий, А.К. Караулов. - к.: Техніка, 1975.-408с.

7. Тененбаум М.М. Сопротивление абразивному изнашиванию / М.М. Тененбаум.М.: Машиностроение, 1976.-270с. 
8. Ткачёв В.Н., Резервы решения проблемы абразивного износа / В.Н.Ткачёв -М.: Машиностроение, 2002.-59c.

9. Хрущов М.М. Абразивное изнашивание / М.М.Хрущёв, М.А. Бабичев.- М.: Наука, 1970.- 251c.

10. Покрытие - эффективный метод повышения сопротивления металлических поверхностей абразивному изнашиванию / А.П. Кудрин, В.Ф.Лабунец, И.Б. Дерек, О.А. Вишневский // Матеріали міжнародної науково - технічної конференції АВIA-2004. Т.3.Виробництво і експлуатація авіаційної техніки.- К.: НАУ, 2004.-С.3621-3625

11. Патент №54496 Україна. МПК (2009) В23К 10/00.- №54496; заявл.20.05.2010; опубл.10.11.2010, бюл.№21

12. Добровольский А.Г. Абразивная износостойкость материалов: Спраовчное пособие / А.Б. Добровольский, П.И.Кошеленко. - К.: Тэхника, 1989.-128c.

Стаття надійшла до редакції 02.10.2020.

Мельник Олексій Валерійович - аспірант Національного Авіаційного Університету.

Смирнов Ігор Володимирович - д-р техн. наук, професор, завідувач кафедри Інженерії поверхні Національного технічного університету України «Київський політехнічний інститут ім. І. Сікорського».

Лабунець Василь Федорович - к.т.н., с.н.с. Національного Авіаційного Університету.

Чорний Андрій Вячеславович - к. т. н, доцент, , доцент кафедри Інженерії поверхні Національного технічного університету України «Київський політехнічний інститут ім. І. Сікорського». 
O. B. MELNIK, I. V. SMIRNOV, V. F. LABUNETS, A. V. CHORNIY

\section{RESEARCH OF WEAR RESISTANCE OF PLASMA COATINGS IN THE CONDITIONS OF ABRASIVE WEAR}

Reliability and durability of modern technque is directly related to the performance of friction units. To ensure their durability today are used a variety of methods of surface hardening, among which the plasma method is appropriate. Composite plasma coatings were applied to 30 ХГСА alloy steel samples, which have been widely used in tribotechnical systems of aviation equipment. Spraying of powders on the basis of ПГ-СР2 was carried out by a special plasmatron with a partially removed arc and additional blowing of the plasma jet with a concentric stream of shielding gas. Due to the design features and optimal modes, the flow was close to laminar, which provided high productivity of the technological process.

Physical and mechanical, both the coating itself and the system "base-coating" are determined by the results of mechanical bending tests on the installation of the KOGEL model (Germany). The wear resistance of the coatings was determined on a standardized installation for abrasive wear under conditions of non-rigid abrasive $\left(\mathrm{SiO}_{2}\right)$.

The homogeneity of the structure and the adhesive strength of the composite plasma coating was ensured by heating in a muffle furnace to the melting temperature.

Optimization of the composition and microstructure of the sprayed coating made it possible to obtain the necessary physical and mechanical and, directly, tribotechnical characteristics of this friction pair.

According to the results of studies of the coating of the structural composition, the mechanical mixture has low tribological characteristics. Composite coatings which has the intermetallics in the structure as the fillers, have much higher tribological properties. It is noted that more promising are composite coatings based on iron, due to their low cost compared to nickel-based coatings. The mechanism of abrasive wear of plasma coatings for these test conditions is established. The prospects and expediency of the use of plasma spraying for coating parts of aircraft friction units operating in abrasive conditions are substantiated.

\section{References}

1. Tribology: textbook./ MV Kindrachuk, VF Labunets, MI Pashechko, EV Korbut.-K .: Published by the National Aviation University "NAU-print".-2009.-392p.

2. Vinogradov VN Wear on impact//V.N. Vinogradov, GM Sorokin, A.Yu. Albagachev. M .: Mashinostroenie, 1982.-311p.

3. Garkunov DN Increase of wear resistance of details of designs of planes / DN Garkunov, AA Polyakov. - Moscow: Mechanical Engineering

4. Dvoruk VI Scientific bases of increase of abrasive wear resistance of details of cars / V.I. Dvoruk K .: KMUGA, 1987.- 101p.

5. Kashcheev VN Abrasive destruction of solids / VN Kashcheev. - M .: Nauka, 1970. -248p.

6. Reliability and durability of machines / BI Kostecki, IG Nosovsky, LI Бершацкий, А.К. Караулов. - к .: Техніка, 1975.-408c.

7. Tenenbaum MM Resistance to abrasive wear / MM Tenenbaum.- M .: Mashinostroenie, 1976.-270p.

8. Tkachev VN, Reserves for solving the problem of abrasive wear / VN Tkachev -M .: Mechanical Engineering, 2002.-59p.

9. Khrushchev MM Abrasive wear / MM Khrushchev, MA Babichev.- M .: Nauka, 1970.- 251p.

10. Coating - an effective method of increasing the resistance of metal surfaces to abrasive wear / AP Kudrin, VF Labunets, IB Derek, O.A. Vishnevsky // Proceedings of the international scientific and technical conference AVIA-2004. T.3.Production and operation of aircraft.- K .: NAU, 2004.-P.3621-3625

11. Patent №54496 Ukraine. IPC (2009) B23K 10 / 00.- №54496; application 20.05.2010; publ.10.11.2010, bul.№21

12. Dobrovolsky AG Abrasive wear resistance of materials: Reference manual / A.B. Dobrovolsky, PI Koshelenko. - К .: Техника, 1989.-128c. 